\title{
Against the decline, make way for basic research
}

\author{
Daniela Palma
}

Published online: 6 August 2014

(c) Centro P.RI.ST.EM, Università Commerciale Luigi Bocconi 2014

\begin{abstract}
With his report 'Science, the endless frontier', published in the aftermath of World War II, Vannevar Bush, head of the U.S. Office of Scientific Research and Development (OSRD), addressed the extreme relevance of basic research for a country's progress. Basic research is recognized as the major source of new knowledge from which to build the scientific capital of a nation. Weakness in basic research is assumed to be the very reason why a nation is doomed to "be slow in its industrial progress and weak in its competitive position in world trade, regardless of its mechanical skill." Long recognised as a success, Bush's "prophecy" has been recently published in Italian with an introduction of Pietro Greco. Quite interestingly, Greco's comments on Bush's report turn to be effective as an interpretation of Italy's economic decline as a result of the lack of sufficient funding for research, while calling for a key role to be played by basic research in governmental policies for growth.
\end{abstract}

Keywords Vannevar Bush - Lucio Russo - Bush Report · Pietro Greco $\cdot$ Knowledge economy $\cdot$ Economic development

What we often forget are the millions of pay envelopes on a peacetime Saturday night which are filled because new products and new industries have provided jobs for countless Americans. Science made that possible, too.

D. Palma ( $\square)$

ENEA, Lungotevere Thaon di Revel, 76, 00196 Rome, Italy

e-mail: daniela.palma@enea.it
These are the words of Vannevar Bush, scientific advisor to president Franklin Delano Roosevelt, who, in the aftermath of the second world war, presented his report entitled 'Science: The Endless Frontier' [1] on the strategic necessity of pursuing policies of public support for basic research in order to permit a realistic prospective of economic development in the United States. Bush's recommendations turned out to be prophetic in grasping that the turning point, in the course of the twentieth century, is represented by the increasing integration of scientific progress and the growth of collective well-being. But in order for this integration to work and bear fruit it is necessary to ensure full, continuous support for the production of new knowledge, guaranteeing the free play of free intellects, working on subjects of their own choice, in the manner dictated by their curiosity for exploration of the unknown'.

History has proven Bush right, and so why should we reflect again on his exhortations? The truth is that history often has terrible students, or at least very forgetful students, capable of constructing beliefs that are unfounded and essentially harmful in the sphere of political decisions. It is thus with this conviction that Pietro Greco, author of the Introduction to the first Italian version of the Bush report, which has just appeared in Italy (in a translation by Benedetta Antonielli d'Oulx) [2] (Fig. 1), addresses the people of Italy, people, victim by now for too long a time of the belief that money spent on research is a luxury and that the growth of the economy can be guaranteed by some vague, unspecified creativity of Italian genius. In the era of 'knowledge economy', Italy is dragging in something more than a technological lag and looks destined for a sure slide down a steep decline, accumulating broader and broader growth gaps with respect to her most important European partners, unless there is a clear and significant change of direction in the policy of restricting spending on research 


\section{Vannevar Bush Manifesto per la rinascita di una nazione Scienza, la frontiera infinita}

Introduzione di Pietro Greco

- La scienza può contribuire al benessere della nazione solo all'interno di un lavoro di squadra. Ma senza progresso scientifico nessun risultato in altre direzioni, per quanto grande, potrà mai assicurarci la salute, la prosperità e la sicurezza necessarie a una nazione del mondo moderno. -

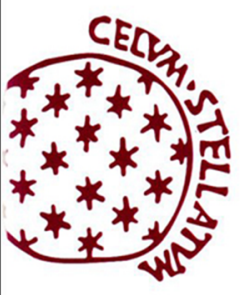

Bollati Boringhieri

Fig. 1 The cover of Manifesto per la rinascita di una nazione

and on the front of the renewal of its manufacturing base, with an increase in the presence of high-tech industries, which have become the driving forces in global demand.

What Greco- through the words of Vannevar Bushaddresses to Italy is a stern warning. As a matter of fact, the long period of abandonment of the policy of massive intervention in the economy that began with the governments of Margaret Thatcher in the UK and Ronald Reagan in the United States has not prevented the governments of most developed countries from continuing to play a significant role in research, nor has it presented the adoption of specific industrial policies aimed at modifying the productive specialisation of the economic system.
Not to mention the fact that in more recent times, the world economy has included new players (China first of all), whose efforts to boost development have increasingly been focused in public investment in research. The idea that a model of 'development without research' will work-even to a limited extent-is completely anachronistic, because the 'knowledge economy' will be the key area in which a country's capacity to create wealth is measured. This means, in other words, that in Italy there are no more excuses for renouncing policies of public investment in research, that there will be less and less room for leverage on price competitiveness through wage compression, and that, as the ongoing economic crisis imposes the selection of effective solutions to revitalise development, there is no more time to lose. For all these reasons and more, it is necessary to start with a careful reading of the Bush report.

Translated from the Italian by Kim Williams.

\section{References}

1. Bush, V.: Science: The Endless Frontier. United States Government Printing Office, Washington, D.C. (1945). https://www.nsf. gov/od/lpa/nsf50/vbush1945.htm. Accessed 29 June 2014

2. Bush, V.: Manifesto per la rinascita di una nazione. Bollati Boringhieri, Torino (2013)

Daniela Palma graduated in Statistics and Economics at the University of Rome in 1989 and worked as a visiting research fellow at the National Center for Geographic Information and Analysis (NCGIA), University of California Santa Barbara, where she prepared her Ph.D. thesis on Quantitative Methods for Economic Analysis (University of Rome "La Sapienza", 1995). Since 1990, she has been working at ENEA (the Italian National Agency for New Technologies, Energy and Sustainable Economic Development) as a researcher in the economics of innovation. Her work has involved empirical economic research dealing with trade, technology and economic development, including themes of regional analysis. She coordinates the activities of a National Observatory of Italy's technological competitiveness. 